\title{
TRADISI DAN KREASI KOSTUM TOPENG BETAWI
}

\author{
Imam Muhtarom, Mochamad Fauzie, Puguh Tjahyono \\ Program Studi Desain Komunikasi Visual, Fakultas Bahasa dan Seni, \\ Universitas Indraprasta PGRI, Jakarta. \\ imam_muhtarom@yahoo.com
}

\begin{abstract}
Abstrak
Tulisan ini membahas peran penting kostum dalam menghadirkan penonton di tengah-tengah pentas topeng betawi. Kostum ditunggu penonton lantaran aneka warna dan aksesorisnya sehingga ketika para penari pentas menjadi menarik dilihat. Kostum tersebut adalah hasil kreasi antara kostum tradisi dan kostum kreasi. Gabungan keduanya berhasil menciptakan kostum-kostum yang memikat penonton untuk melihat pentas topeng betawi. Kostum itulah yang menjadikan topeng betawi tetap memperoleh undangan pentas.
\end{abstract}

Kata kunci: topeng betawi, kostum, tradisi, kreasi, penonton.

\begin{abstract}
This paper discusses the important role of costumes in presenting the audience in the midst of topeng betawi performances. The costumes awaited the audience because of the various colors and accessories so that when the dancers perform to be interesting views. The costume is the result of a creation between traditional costume and costume creations. Combined both managed to create the costumes that captivate the audience to see the performances of topeng betawi. Costume that makes topeng betawi still get a stage invitation.
\end{abstract}

Keywords: topeng betawi, costume, tradition, creation, audiences 


\section{PENDAHULUAN}

Saat ini seni tradisi mengalami pelbagai tantangan dalam hal keberlanjutannya. Tantangan yang paling nyata adalah surutnya pentas di tengah perubahan zaman. Menurunnya pentas ini terkait dengan beragamnya hiburan yang tersedia, generasi yang berganti, dan perubahan dalam komunitas pendukung dari seni tradisi bersangkutan.

Adanya banyak hiburan dari televisi, internet, ipod, film layar lebar sebagai bagian dari modernitas membuat semakin kurangnya peminat seni tradisi. Media hiburan tersebut setiap saat terus berubah, baik dari sisi konten maupun mediumnya, sehingga membuat penonton banyak menikmati media audiovisual daripada menonton pertunjukan seni tradisi.

Generasi pemirsa seni tradisi terus berganti. Dalam pekembangan waktu generasi lama akan digantikan oleh generasi baru. Seni tradisi yang dihidupi oleh generasi lama tidak mendapat penerusnya pada generasi baru. Alasannya beragam, mulai dari tidak menarik sampai tidak adanya peluang ekonomi di dalamnya.

Kemudian yang paling pokok adalah perubahan komunitas seni tradisi bersangkutan. Komunitas adalah sejumlah orang yang hidup bersama di suatu tempat dan terikat oleh kebudayaan yang sama (Ninuk Kleden, 1996, hal 101). Komunitas sebagai pemilik tradisi telah berubah seiring perkembangan zaman. Perubahan komunitas menyebabkan seni tradisi perlahan kehilangan fungsinya di kalangan anggota komunitas. Komunitas tidak lagi menempatkan tradisi menjadi bagian yang penting dalam kehidupan mereka. Di sinilah muncul persoalan tradisi kehilangan konteks sosialnya.

Topeng betawi sebagai bagian dari tradisi komunitas Betawi juga menghadapi persoalan keberlanjutan. Persoalan munculnya banyak hiburan modern, pergantian generasi, dan perubahan komunitas menjadi tantangan bagi keberlanjutan topeng betawi.

Dalam menghadapi tantangan ini telah banyak yang dilakukan baik eksternal maupun internal. Tindakan eksternal antara lain menguatkan peran sanggar, bantuan dana maupun pertunjukan dari pemerintah DKI, dan kerjasama dengan korporasi. Sementara dari sisi internal dilakukan regenerasi dan perubahan dalam pertunjukan topeng betawi. Perubahan pertunjukan ini diharapkan memunculkan ketertarikan pada generasi yang ada sekarang pada seni tradisi tersebut. Perubahan dalam aspek pertunjukan disebut kreasi baru.

Tulisan ini beranjak dari adanya kreasi baru pada tarian dalam pertunjukan topeng betawi, khususnya mengenai kostum penari akan menarik minat penonton. Adapun pertunjukan topeng betawi berupa pergelaran teater yang didukung oleh musik, tari, dan kostum. Karena itu, narasi menjadi bagian utama atau dominan dari pentas topeng betawi. Sementara itu, unsur musik, tari, dan kostum berfungsi sebagai pendukungnya. Pertanyaannya: apakah kreasi baru kostum bisa meningkatkan minat penonton, padahal kostum bukan unsur dominan dari pertunjukan topeng betawi?

\section{METODE PENELITIAN}

Artikel ini ditulis berdasarkan hasil penelitian "Strategi Visual Kostum sebagai Unsur Kreasi baru Topeng Betawi dalam Rangka Meningkatkan Minat Penonton". Adapun pendekatan penelitian ini adalah kualitatif dengan menggunakan metode etnografi.

Penelitian ini dilakukan pada pertunjukan topeng betawi yang dilakukan oleh Kelompok Margasari Kacrit Putra yang beralamat di Kampung 
Jati No. 44 RT 003 RW 07 Kel. Jatimulya, Kec. Tambun Selatan, Bekasi, 17515.

Penelitian ini hendak mengungkap strategi visual kostum topeng betawi dalam kaitannya dengan ketertarikan penonton. Dalam penelitian ini dilakukan model partisipasi terhadap para pelaku seni topeng Betawi untuk mengetahui lebih mendalam topik penelitian.

Selanjutnya dengan menetapkan informan kunci terlebih dahulu, pada penelitian ini dilakukan wawancara mendalam terhadap para informan kunci yang dianggap bisa memberi informasi terkait topik penelitian.

Kemudian setelah data diperoleh akan dilakukan analisis data dengan menggunakan kualitatif deskriptif.

\section{PEMBAHASAN}

Berkenaan dengan kreasi baru Endang Caturwati (2007) mengatakan kreasi baru merupakan karya yang dihasilkan atas kreativitas indvidual atau kelompok, sebagai karya yang ditata dengan sentuhan atau cita rasa baru. Kreasi baru dalam seni pertunjukan bisa diamati pada gerak tari, musik, kostum, dan pencahayaan.

Selanjutnya, Arthur S Nalan (1996) berpendapat tari kreasi merupakan hasil ciptaan tari yang muncul sekitar tahun 1950-an yang kerap disebut dengan tari kreasi baru. Tari kreasi baru merupakan wujud garapan tari yang hidup relatif masih muda, lahir setelah tari tradisi berkembang cukup lama. Dalam garapan tariannya terdapat tanda adanya pelbagai pembaharuan. Menurut Nalan, kreasi baru dalam tari kreasi ada pada gerak tari, musik, dan kostum.

Dalam konteks topeng betawi kreasi baru adalah perubahan dalam pertunjukan dengan tujuan menarik minat para penonton. Menurut pakar budaya Betawi, Yahya Saputra (2016), perubahan penting dalam topeng betawi ada pada unsur tarian. Unsur perubahan tari ini ini meliputi pencahayaan, busana, musik, dan gerak. Sementara unsur cerita dan para aktornya cenderung tidak berubah. Padahal pada tahun 1970-an akhir atau awal tahun 1980-an belum ada perubahan seperti itu, bahkan untuk pentas topeng betawi dilangsungkan masih di tanah (Ninuk Kleden, 1987).

Dalam penelitiannya, Praycita Utami (2013) menunjukkan bahwa kostum dan aksesoris yang dipakai penari topeng betawi bagian dari kreasi baru. Selain mementaskan gerak yang baru dalam tari kreasi, terdapat kostum yang baru. Tujuan dari kreasi baru ini semata adalah menarik penonton yang lebih banyak. Sesuai dengan sasaran yang hendak dituju dari adanya tari kreasi ini, asumsinya ada kesesuaian antara tari kreasi dengan ketertarikan penonton. Kesesuaian ini termasuk di dalamnya adalah kesesuaian dalam hal kostum.

Dengan demikian, visualisasi kostum berperan dalam menentukan minat penonton terhadap pertunjukan topeng betawi. Pelaku seni topeng betawi menentukan unsur kostum yang terdiri dari warna, bentuk, dan bahan serta komposisi dari unsur-unsur tersebut.

Perhatian akan pentingnya kostum telah ada pada pelaku seni dari topeng betawi. Perhatian ini berasal dari pentingnya penampilan sebuah pentas yang menarik penonton. Kostum topeng betawi dipentaskan dengan banyak variasi secara visual, tidak monoton, memiliki ciri khas, dan mampu bersaing dengan tampilan dari kelompok seni topeng betawi lainnya. Juga, topeng betawi ini memosisikan diri bersaing atau paling tidak beradaptasi dengan seni modern. Untuk itu, tampilan pentas dari kostum menjadi perhatian.

Penyesuaian pertunjukan agar mendapat apresiasi yang bagus dari penonton sudah biasa dilakukan pada 
pergelaran seni tradisi. Misalnya, kirab budaya di Kota Gede, Yogyakarta melakukan penyesuaian guna meraih penonton dalam jumlah besar. Sekalipun kirab budaya dilakukan di Kota Gede, kirab budaya menghadirkan objek budaya Jawa seperti gunungan, siraman, abdi dalem, kostum prajurit keraton, dan kostum bregada (prajurit perempuan). Padahal, kirab budaya ini dilakukan di Kota Gede, yang disebut lekat dengan Islam, khususnya Muhammadiyah. Menurut para abdi dalem yang menjadi pencetus kirab budaya yang diselenggarakan sejak 2009 menyatakan bahwa kirab budaya tersebut sebatas bermaksud mempromosikan produk kerajinan perak dan makanan khas Kota Gede serta menarik minat para turis (Judith Schele, 2017).

Pelaku seni topeng betawi dari Kelompok Margasari Kacrit Putra, Bekasi, Jawa Barat telah melakukan kreasi kostum penari sebagai cara menarik minat penonton. Kreasi kostum dilakukan pada kostum tari kreasi maupun pada tari tradisi. Pada tari kreasi bersifat bebas meskipun tetap memanfaatkan bentuk-bentuk tradisi dalam pembuatannya. Sementara pada tari tradisi, kostum tetap dibuat dengan pendekatan tradisi namun memasukkan unsur-unsur baru sebagai bagian dari kreasi.

Dalam tari tradisi yang dipertahankan yaitu kembang topeng (tutup kepala), pola 3 warna pada lengan, toka-toka (dada), ampreng (perut ke bawah), rok batik, andong (rok transparan menutup rok batik; biasa disebut tampol), dan selendang. Unsur yang dipertahankan ini dapat diubah dalam pola, warna, bahan sesuai selera yang diinginkan oleh pihak grup, yang dalam hal ini pimpinan (Syamsudin atau Bang Udin) dan istrinya (Silvia).
Menurut Bang Udin dan Silvia berikut penempatan dan fungsi unsur kostum tradisi:

1. Kembang topeng dikenakan sebagai penutup kepala.

2. Toka-toka dikenakan di dada, sekaligus berfungsi menutupi dada.

3. Pola tiga warna pada pakain yang terletak di antara kedua lengan atas dan sikut penari.

4. Ampreng dikenakan di perut, sekaligus berfungsi menutupi perut.

5. Kain batik dikenakan sebagai rok.

6. Andong untuk menutupi pantat.

7. Selendang untuk perangkat menari.

Kreasi dalam kostum meliputi beberapa hal, antara lain warna, pola, bahan. Bisa dikatakan tidak ada batasan dalam olah kreasi karya kostum dalam topeng betawi Kelompok Margasari Kacrit Putra, Bekasi. Warna diambil dari sumber mana saja, tidak terbatas dalam keseharian budaya Betawi. Pola berubahubah, sekalipun pada unsur tari tradisi. Misal, pada toka-toka. Sebelumnya tokatoka terdiri dari dua kain yang diselempangkan di dada penari tradisi sehingga membentuk pola $X$ di dada penari. Dua kain ini diikat di punggung penari. Saat ini, tidak hanya dua kain, tetapi satu kain yang langsung dikenakan pada leher penari. Hal ini tampak lebih praktis pada kostum penari. Ini terjadi pada semua unsur kostum tari tradisi.

Dari sisi bahan ada perubahan banyak. Misalnya, pada toka-toka dibuat dari bahan yang agak kaku, misalkan beludru. Dari beludru ini ditempelkan pernik-pernik hiasan permata imitasi dan payet di sekujur bagian depan toka-toka. Tampak ada kemewahan dari hiasan imitasi ini dan hiasan ini secara fungsional akan memantulkan cahaya pada saat terkena sorot lampu panggung (lighting). Jadinya, sebuah visual yang meriah.

Dalam menyusun warna, mereka menghindari warna "mati", misal warna 
hitam dan merah yang paduannya menjadi warna gelap. Warna diupayakan harus warna yang hidup, misalnya warna kuning ketemu merah. Warna keemasan ketemu merah. Warna-warna demikian menurut Bang udin (42) dan istrinya Sylvia (36) menunjukkan warna yang "hidup". Enak dipandang, kata mereka.

Padu-padan yang dilakukan pada warna misanya, antara warna merah muda, pink, dan warna emas. Tampak warna ini cukup megah dan Silvia bilang merupakan jenis warna "kota". Warna kota adalah warna yang dalam konteks masyarakat Betawi disebut warna yang bagus, berbalik dengan warna kampung yang disebut warna yang norak, kampungan.

Berikut unsur dalam kreasi baru pada kostum dalam rangkaian pertunjukan Topeng Betawi dalam pentas kelompok topeng betawi Margasari Kacrit Putra. Pentas dilaksanakan pada Sabtu, 19 Agustus 2017 di Kampung Ciketing, Rawa Mulya, Bekasi Timur, Jawa Barat.

Pentas dimulai pada pukul 20.00 diawali dengan adanya tetalu, yaitu pertunjukan musik topeng betawi. Fungsi lain tetalu adalah memberitahu penonton bahwa pertunjukan topeng betawi sudah dimulai. Malam itu dipertunjukan 5 tarian dari grup ini, yaitu tari dasar, tari gegot, tari tunggal, tari sarendong ajer, dan tari lipet gandes. Kelima tari ini diantaranya ada tari tradisi dan tari kreasi. Tari tradisi, yaitu tari dasar, tari gegot, tari topeng tunggal, dan tari lipet gandes. Sementara tari kreasi adalah tari sarendong ajer.

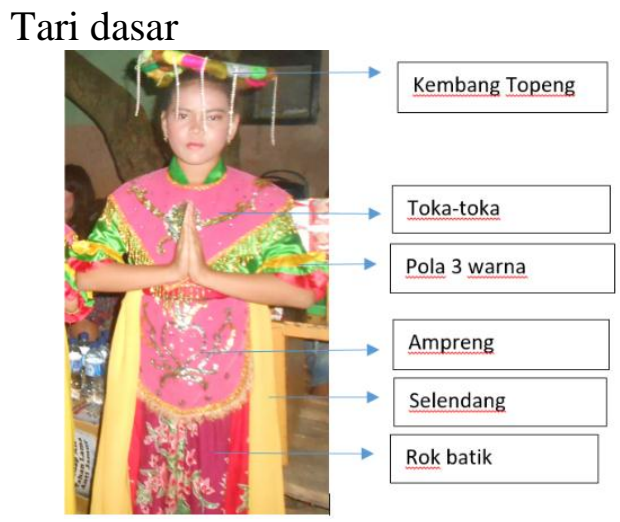

Gb. 1. Kostum tari dasar

Tari dasar dimainkan oleh anakanak untuk pembuka sebuah pentas topeng betawi. Urutannya setelah tetalu berakhir kemudian para penari tari dasar muncul di panggung. Tarian ini merupakan tari tradisi sehingga ada 7 unsur yang dapat dikenali, yaitu pada kembang topeng, toka-toka, warna 3 pola, ampreng, selendang, rok batik, dan andong.

Sekalipun kostum yang dikenakan menggunakan pakem tradisi, bisa kita lihat kreasi kekinian di balik kostum tradisi tersebut. Warna pada kembang topeng lebih cenderung pada warna dingin minus warna panas. Warna pada kembang topeng adalah cokelat, hijau, abu-abu, dan sedikit kuning dan merah. Kemudian dihiasi oleh rumbai warna putih di batas pinggir kembang topeng.

Pada toka-toka secara tradisional polanya adalah dua kain melintang di dada. Pada kostum tari dasar ini penari mengenakan pola utuh di dada dengan sebutan tetap toka-toka yang fungsinya adalah menutupi bagian dada. Warna yang digunakan adalah merah muda atau cenderung pink dengan hiasan berupa bordir warna keemasan menyusun bentuk sulur dedaunan. Kemudian di pinggirannya terdapat rumbai yang disusun rapat. Dalam hal ini dapat dikatakan toka-toka telah mendapat kreasi yang baru.

Adapun pola tiga warna di lengan kanan dan kiri merupakan susunan warna kuning-hijau-merah. Dalam hal pola 
adalah tradisi, sementara dalam hal warna adalah kreasi. Warna dalam pola ini berubah-ubah dan ciri khas yang melekat ada pada tiga pola warna tersebut.

Kemudian pada ampreng menggunakan warna merah dan bordir warna emas. Warna ini merupakan unsur kreasi, sedangkan tradisi pada bentuk desainnya. Lalu pada rok batik menggunakan warna dasar merah tua dengan hiasan berupa motif bunga warna hijau dan putih. Selanjutnya, ada selendang yang terjatuh ke bawah warna kuning di antara dominasi warna merah pada kostum tari dasar ini.

Secara visual terlihat warna merah dominan pada kostum tari dasar ini. Tari dasar yang termasuk dalam ranah tari tradisi mendapat sentuhan warna yang dominan merah dengan diimbangi warna kuning pada selendang. Sehingga warna hijau pada kemeja penari tampak sengaja dibuat "tenggelam". Warna menyala ini dalam pengertian Silvia maupun Bang Udin selaku pimpinan disebut sebagai warna ngejreng, warna menyala sebagai salah satu ciri dari kostum penari topeng betawi,

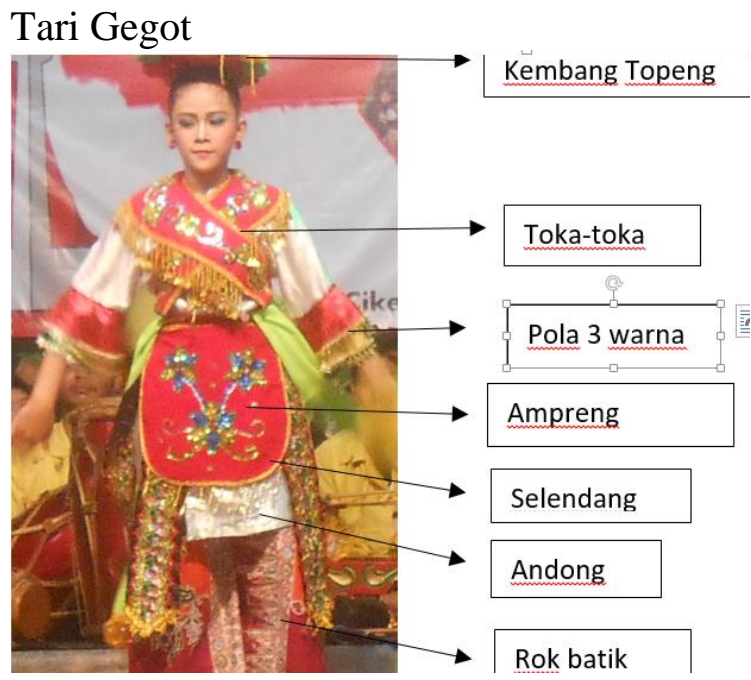

Gb. 2. Kostum tari gegot

Kostum pada tari gegot ini juga didominasi oleh warna merah. Toka-toka yang melintang masih menggunakan desain tradisional, yaitu desain dua bidang kain melintang di dada penari. Warna merah dihias oleh bordir emas dengan motif bunga. Pada sisi bawah dihias dengan rumbai warna kuning.

Kembang topeng yang melekat di kepala penari juga didominasi warna merah kemudian muncul warna kuning dan hijau. Sementara untuk rumbainya menggunakan warna kuning. Hal ini sejalan dengan warna ampreng yang tampak luas di area perut ke bagian bawah. Warna merah terlihat menyala dengan hiasan bordir warna emas. Kemudian pola tiga warna di lengan kanan dan kiri penari ada warna merah, hijau, dan putih. Hanya saja, dua warna selain merah tenggelam oleh warna merah. Di ujung masing-masing warna di tiga pola ada hiasan rumbai warna kuning.

Untuk rok batik pada tari gegot menggunakan batik yang didominasi warna merah dengan sedikit hiasan warna putih. Pada rok batik ini melintang ke bawah dua selendang yang fungsinya bukan untuk perlengkapan menari, melainkan lebih pada hiasan. Warna dasarnya sebenarnya merah tetapi didominasi oleh hisan berupa bordir dan payet warna kuning dan putih mengkilau. Bahannya sejenis beludru sehingga tampak kaku dan dapat menahan goyangan penari. Dengan demikian, hiasannya akan tampak maksimal terlihat oleh penonton.

Sementara itu, selendang untuk menari berwarna hijau muda. Warna ini tidak memberi kontras pada keseluruhan warna dominan merah. Warna ini cenderung memberi nuansa lain ketika difungsikan sebagai sarana menari dengan warna hijau mudanya.

\section{Tari Tunggal}

Pada tari tunggal tersebut tetap dipertahankan unsur pembentuk tari tradisi. Ada 7 unsur pembentuk tari 
tradisi pada tari topeng tunggal, yaitu kembang topeng, pola 3 susun, toka-toka, selendang ampreng, rok batik, dan andong. Ketujuh unsur ini menjadi ciri sekaligus identitas dipertahankannya bentuk tari tradisi dalam tari topeng tunggal. Selain itu ada 1 unsur lainnya, yaitu topeng atau kedok yang berjumlah tiga buah, berwarn putih, merah muda, dan merah tua.

Adapun letak kreasi pada tari tunggal terletak di luar 7 unsur tersebut. Warna pakaian biru muda dan biru laut di kemeja merupakan paduan bebas yang lepas dari batasan tradisi. Warna biru muda yang dominan bagian dada dan warna biru laut pada lengan yang membentuk pola tiga warna adalah warna serasi. Warna ini merupakan bagian dari kreasi tari tunggal.

Demikian juga warna pada kembang topeng. Paduan warna merah, kuning, dan sedikit hijau adalah bentuk kebebasan kreatif. Demikian juga susunan yang kemudian membentuk setengah lingkaran adalah buah dari kreasi baru. Kembang topeng dalam tinjauan tradisi terletak pada bentuk setengah lingkaran kemudian terdapat rumbainya. Sementara susunan yang membentuk dan warna muncul dari kebebasan kreatif.

Pada toka-toka kreasinya terletak pada pilihan warna dasar putih mengkilau. Sementara motif yang ada di dalamnya beserta payet-payet yang ada adalah bentuk kreasi baru. Demikian juga pada rumbai di bgaian bawah toka-toka tidak ada pada ketentuan tradisi. Karena itu, termasuk bagian dari kreasi baru.

Warna merah pada selendang adalah pilihan bebas atau disebut kreatif. Juga warna putih sekaligus pola hiasan pada ampreng adalah pilihan kreatif. Warna dasar batik pada rok batik termasuk di dalam unsur kreasi baru.

Kostum penari tunggal ini secara keseluruhan didasari warna biru laut dan biru muda dengan kombinasi putih berkilauan. Biru muda dan biru laut menjadi ekpresi yang kuat pada kostum tari tunggal. Adapun warna kontrasnya ada pada warna merah, sedikit kuning, dan sedikit lagi warna emas. Secara komposisi warna kontras ini memberi sentuhan kehangatan pada warna dingin biru laut dan biru muda. Sebuah komposisi warna yang enak dilihat.

\section{Tari Lipet Gandes}

Berikut kostum tari lipet gandes sebagai sebuah tari tradisi. Fungsi dari lipet gandes ini adalah pembuka pada bagian drama. Tari lipet gandes mengawali adanya kemunculan drama. Berikut foto dari lipet gandes:

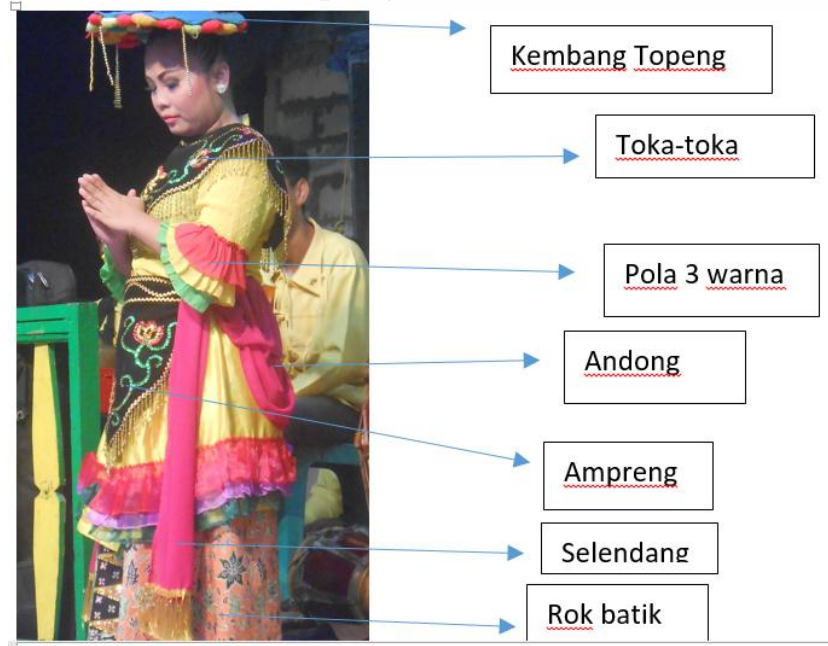

Gb. 3. Kostum tari lipet gandes

Dalam tinjauan tradisi topeng betawi, kostum tari lipet gandes di atas terdiri dari 7 unsur. Adapun ketujuh unsur tersebut adalah kembang topeng, tokatoka, pola lengan 3 warna, andong, ampreng, selendang, dan rok batik.

Pada kostum tari lipet gandes ini kembang topeng disusun oleh warna kuning-merah dan bagian atas warna biru tua. Adapun toka-toka desainnya tidak melintang dari dua kain, melainkan satu kain warna hitam. Secara tradisi, bentuk toka-toka melintang di dada. Pada tokatoka ini bentuknya satu bidang utuh berupa kain beludru warna hitam yang 
secara praktis dikenakan pada leher dan menutupi dada penari. Toka-toka warna hitam dihiasi payet warna hijau. Dari pilihan bahannya, toka-toka ini terbuat dari kain beludru yang kaku. Adanya sifat kaku ini memudahkan payet tertempel dengan baik dan ketika penari bergerak cepat dapat melekat dengan baik pada dada penari.

Sifat ini juga ada pada ampreng yang bahannya berasal dari beludru. Jenis beludru ini mudah ditempeli payet hijau berkilauan. Kemudian warna hitam sebagai kreasi dari kostum memberi

Tari Sarendong Ajer warna kontras pada warna pakaian yang didominasi warna kuning.

Kemudian selendang warna merah yang merupakan hasil kreasi memberi kontras lain pada dominasi warna kuning. Warna panas ini memberi kesan menyala bagi keseluruhan warna yang ada pada kostum penari lipet gandes. Ini kreasi yang tidak ada pada pakem tradisi.

Pada rok batik tampak warna yang agak kalem dengan dasar warna krem. Adanya warna kalem ini membuat warna kuning dan warna merah kian menyala. Rok batik ini semakin menegaskan dominasi pada warna kuning dan merah.
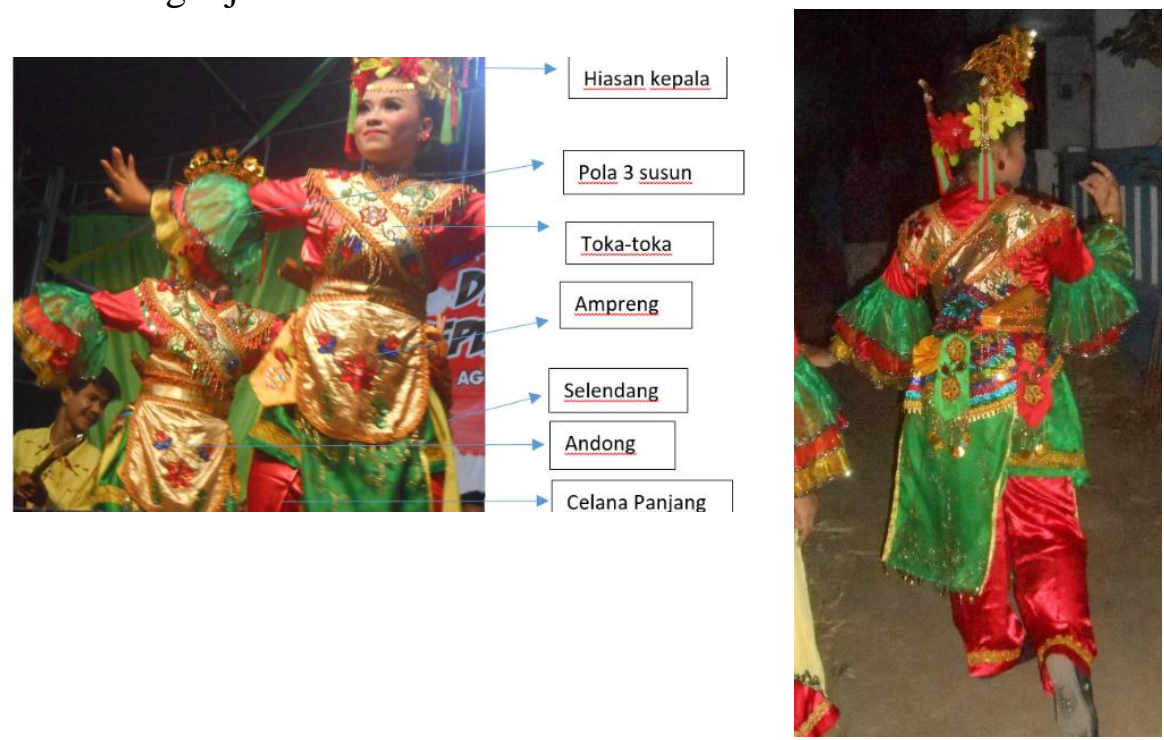

Gb. 4. Kostum tari sarendong ajer

Tari yang dimaksudkan sebagai tari kreasi adalah tari sarendong ajer. Tari ini disebut tari kreasi sebab baru diciptakan dan karya dari Bang Udin. Tari sarendong ajer memiliki arti kata, yaitu sarendong berarti jenis bunga di Bekasi dan kata ajer berarti murah. Tari ini dimaksudkan untuk merayakan suka-suka di antara kaum muda. Tema dalam tarian ini adalah keriangan pada jiwa kaum muda. Tarian ini dimainkan oleh lima penari perempuan.

Kreasi pada tari ini adalah dari sisi tutup kepala yang berwarna kuning keemasan. Tutup kepala ini terbuat dari bahan keras sejenis kawat yang dihias oleh bunga imitasi warna kuning dan merah di kepala penari. Para penari ini tidak mengenakan kembang topeng sebagai ciri dari tari tradisi dari topegn betawi.

Kreasi lainnya ada pada celana. Dalam tari tradisi tidak ada penggunaan celana. Tradisi pasti mengenakan rok dan terbuat dari kain batik. Dalam kostum tari sarendong ajer ini terdapat perbedaan yang jelas dengan hadirnya celana. Dengan celana gerak kaki penari akan lebih leluasa dibandingkan dengan rok. Selanjutnya, adanya kreasi dengan 
hadirnya kipas warna kuning. Para penari memegang kipas warna kuning yang membuat gerak semakin dinamis ketika menari.

Namun demikian, kostum tarian ini masih menggunakan toka-toka dalam pola tradisi, pola 3 warna, ampreng, andong, dan selendang. Kostum dalam tarian ini merupakan paduan dari warna merah, warna emas, dan warna hijau. Ada kesan mewah ketika merah dan warna emas saling berkombinasi. Dan dua warna hangat ini berusaha diredakan oleh warna hijau yang berkecenderungan warna dingin.

\section{Kostum Kreasi dan Penonton}

Mengamati kostum dan pentas topeng betawi di Bekasi menimbulkan beberapa hal, khususnya mengenai strategi visual kostum penari topeng betawi untuk menarik minat para penonton. Kreasi yang ada pada kostum meliputi pencarian bentuk atau pola, penggunaan warna, bahan, dan adanya aksesoris. Keempat hal tersebut dipadupadankan sedemikian rupa sehingga membentuk kostum utuh pada penari. Unsur-unsur tersebut menjadi sarana untuk menciptakan kostum-kostum yang dianggap bagus dan layak untuk pentas pada sebuah pertunjukan topeng betawi.

Pada pentas pada Sabtu, 19 Agustus 2017 di Bekasi menunjukkan upaya Kelompok Margasari Kacrit Putra untuk membuat sebuah tarian menjadi menarik dengan kostum khusus. Kostum itu didesain secara khusus dengan detaildetail yang berbeda satu kostum dengan kostum yang lain. Kostum menandai kekhasan pada sebuah tarian sekaligus menjadi pembeda antartarian. Kostum tari dasar memiliki perbedaan dengan kostum tari gegot. Begitu pula kostum tari tunggal dapat secara mudah dibedakan secara kostum dengan tari sarendong ajer. Begitu pula dengan kekhasan pada tari lipet gandes.
Dengan demikian, akan diperoleh sebuah tarian yang berbeda tidak hanya pada sisi koreografi, tetapi juga pada kostum. Kostum selain untuk mewakili ekspresi dari tema tarian bersangkutan memiliki tujuan agar menarik di dalam penglihatan penonton. Gagasan ini secara lugas disampaikan oleh Bang Udin. Kostum berperan penting dalam tampilan sebuah topeng betawi. Kostum bahkan lebih penting daripada kostum di dalam bagian drama di topeng Betawi. Kata Bang Udin,

"Pada bagian drama, kostum sekadar mewakili peran dari para pemain saja. Pemain (aktor) juragan mengenakan kostum juragan. Demikian juga kostum petani atau kostum ibu rumah tangga.... Kostum pada tarian bisa lebih bebas dan akan lebih berpengaruh pada penonton."

Pendapat serupa juga dikuatkan Ibu Silvia yang berperan sebagai desainer dalam pembuatan kostum pada Kelompok Topeng Betawi Margasari Kacrit Putra,

"Kostum pada pemain drama sama dengan kostum dalam kehidupan sehari-hari, sedangkan pada kostum tari berbeda. Kalau peran guru, kostumnya ya kostum guru. Jadinya, biasa aja ya kostumnya... Lebih menarik pada kostum tari yang bisa kreatif dan inovatif."

Kostum dalam pentas di topeng Betawi menempati posisi yang penting bagi pihak di luar pelakunya. Dari sisi alasan pihak pemilik hajat, kostum menjadi unsur yang dipertimbangkan untuk mengundang Kelompok Margasari Kacrit Putra dan bukan kelompok topeng betawi yang lain.

Dalam keputusan untuk mengadakan sekaligus memilih kekompok topeng betawi mana yang tampil, ketua RT dan Ketua RW tidak menentukan secara personal. Kedua perangkat di bawah kelurahan ini menyerahkan segala putusan kepada warga. Hal ini terpapar dalam sebuah rapat persiapan HUT RI ke- 
72 di RT 004 RW 01 Kampung Ciketing, Rawa Mulya, Bekasi.

Meski begitu sebagai ketua RW 01, Muhamad Sarif (45 tahun) memiliki pengaruh dalam menentukan pemilihan kelompok topeng betawi mana yang akan tampil pada malam perayaan HUT RI yang akan pentas. Ketua RW ini berpendapat bahwa kostum yang dikenakan oleh para penari bagus-bagus. Para penari selalu berganti kostum apabila ganti jenis tarian. Dengan demikian, penampilannya menjadi menarik dan panggungnya menjadi variatif.

Memang, keputusan memilih Kelompok Margasari Kacrit Putra tidak semata kostum. Faktor lainnya, misalkan, ketenaran, bintang panggung, pemainnya kebanyakan masih muda. Hal senada juga disampaikan Ketua RT 001, Mahmud (60 tahun), bahwa kelompok ini dipilih lantaran adanya kelengkapan pada waktu pertunjukan. Dalam pertunjukannya terdapat gambang kromong, tari-tarian, musik dangdut, dan lawak. Namun Mahmud juga menyatakan bahwa kostum kelompok ini menarik sehingga bisa ikut memperkenalkan berbagai kostum kepada generasi muda. Agar, kata Mahmud, mereka mengenal seni budaya Betawi.

Apa yang disampaikan pihak grup yang dinyatakan oleh Bang Udin selaku pimpinan dan Silvia selaku desainer kostum sejalan dengan pendapat pemilik hajat, yang dalam hal ini diwakili oleh Ketua RT dan Ketua RW. Keduanya dapat dikatakan representasi dari warga RT 001 sebagai pemilik hajat sesungguhnya pada pentas Sabtu, 19 Agustus 2017 di Kampung Ciketing, Rawa Mulya, Bekasi.

Akan halnya penonton sebagai penikmat sesungguhnya dari penonton sekaligus pemilik seni tradisi topeng betawi terdapat pendapat beragam soal kostum. Kostum pada sebagian penonton merupakan unsur yang menarik pada pertunjukan topeng malam itu. Namun, sebagian penonton lain mengatakan bahwa kostum tidak mereka tunggutunggu. Penonton ini menunggu bodoran atau lawakan. Dalam pertunjukan topeng betawi yang mereka harapkan adalah adanya bodoran yang menggelikan.

Nur (55 tahun) mengatakan pertunjukan topeng betawi dari Kelompok Margasari Kacrit Putra selalu menarik. Kostum yang mereka kenakan bermacam-macam. Setiap tarian yang naik panggung selalu dengan kostum yang berbeda. Ia melihat dandanan yang dikenakan pada penari berbeda-beda. Mulai dari warna, banyaknya aksesoris yang dikenakan, dan desain kostum. Kata Nur,

"Dulu pada saat saya masih muda, kembang topengnya cuma itu-itu saja."

Maksud kata "itu-itu" saja dari segi jenisnya hanya satu kembang topeng, yaitu kembang topeng berupa setengah lingkaran yang menutup kepala dengan hiasan rumbai. Saat ini dalam Kelompok Margasari Kacrit Putra tidak hanya kembang topeng yang dipakai penari, tetapi tutup kepala dengan jenis berbeda. Untuk itu, sesungguhnya namanya bukan kembang topeng, melainkan tutup kepala atau hiasan kepala saja.

Pendapat Nur ini memberikan gambaran akan perbedaan pentas kelompok topeng betawi ini dari era dia masih muda, bahkan masih kecil, dengan pentas malam itu. Penampilan Kelompok Margasari Kacrit Putra lebih menarik dikarenakan adanya banyak variasi kostum yang dikenakan penari.

Tekanan pada kostum yang dikenakan pada penari muncul dari penonton bernama Fitrah Anugerah (44 tahun). Ia berpendapat penari dengan balutan kostum seperti pada pertunjukan Kelompok Margasari Kacrit Putra membuatnya tertarik menonton topeng betawi. 
"Penarinya cantik-cantik," kata Fitrah. Ia mengaku sering menonton topeng betawi, tidak hanya dari kelompok Margasari Kacrit Putra di kawasan Bekasi. Ia selalu menunggu tari-tarian yang dibawakan oleh para perempuan cantik.

Pendapat serupa dengan tekanan berbeda muncul pada penonton bernama Kokom (33 tahun). Dengan terang ia menyatakan lebih menyukai tariannya daripada bodoran. Kata Kokom,

"Kostumnya menarik dari sisi warna, banyak variasi warnanya. Yang (saya) ditunggu adalah tariannya. Kostumnya lengkap terlihat (dari) aksesoris."

Menurutnya, tarian sarendong ajer yang dibawakan Kelompok Margasari Kacrit Putra adalah tarian yang menarik. Kostumnya terasa mewah dan cantik. Sementara, bodoran malam itu dangkal. Jadinya, ia tidak terlalu suka dengan bodoran. Padahal, sudah menjadi kebiasaan umum bodoran adalah bagian yang paling sering ditunggu-tunggu oleh penonton. Di sini pendapat Bang Udin dan Silvia juga pendapat pemilik hajat sejalan dengan pendapat penonton. Kostum memiliki peran besar dalam pertunjukan topeng betawi dalam kaitannya untuk menumbuhkan minat ketertarikan pada diri penonton. Secara visual kostum dapat memberi pengaruh penonton untuk menyukai pentas topeng betawi. Visual yang menarik ini membentuk citra yang melekat pada diri seseorang (penonton) dan melebihi aspek-aspek lainnya. Hal ini sejalan pendapat John Berger berkenaan dengan dengan kekuatan visual dibandingkan kata-kata (1972, hal. 7).

Namun demikian, pendapat tersebut tidak bulat. Kostum tidak selalu menjadi unsur penentu ketertarikan penonton ketika melihat topeng betawi. Dibandingkan dengan kostum, para penonton ini menyukai sekaligus menunggu-nunggu bagian bodoran atau lawak. Mereka menonton hingga pertunjukan topeng betawi berakhir.

Penonton bernama Herman (30 tahun) mengatakan bahwa yang ia tunggu dari pentas topeng betawi adalah bodoran. Bodoran topeng betawi selalu menarik hatinya, apalagi yang pentas adalah Kelompok Margasari Kacrit Putra. Ia berpendapat kostum dari kelompok ini terbilang bagus. Namun secara pribadi ia tetap menunggu kehadiran bodoran pada setiap pertunjukan topeng betawi, utamanya kelompok ini. Kata Herman,

"Bodorannya yang selalu menarik dan membuat tertawa-tawa."

Pendapat ini serupa dengan Moh. Saleh (40 tahun). Ia mengenal pertunjukan kelompok ini semenjak ia masih kecil. Dalam setiap pertunjukan topeng betawi ini ia selalu menunggu bagian bodoran. Unsur-unsur lain semacam musik atau tarian tidak terlalu menjadi perhatiannya.

Indra (25 tahun) juga memiliki pendapat tentang menariknya bodoran. Ia lebih suka bodoran dibandingkan dengan tarian. Ia tidak terlalu memperhatikan ketika ada tarian. Bahkan penonton bernama Evi (35 tahun) secara terus terang mengatakan dalam setiap menonton topeng betawi yang ia tunggutunggu adalah kemunculan bodoran. Ia menganggap tidak penting kehadiran taritarian. Ia merasa tari-tarian topeng betawi membuatnya bosan, termasuk pentas tari yang dibawakan kelompok Margasari Kacrit Putra malam itu. Katanya,

"Pentas tarinya terlalu lama, ya. Padahal, saya ingin lekas menyaksikan bodoran."

Nur, seorang penonton, yang di awal mengatakan kostum kelompok ini menarik, sesungguhnya masih kalah seru dengan pertunjukan ketika ia masih muda. Kata Nur,

"Dulu ada bagian drama yang berisi kisah para jagoan. Seru, ya, dibandingkan saat ini. Sekarang (kisah 
jagoan) sudah tidak ada lagi. Paling yang ada cuma bodoran."

Pendapat dari para penonton di atas tidak secara bulat atau keseluruhan menyatakan bahwa unsur kostum yang dikenakan penari sebagai hal yang menarik perhatiannya. Bahkan ada penonton yang merasa tari-tarian itu terasa mengganggu, sebab bagian bodoran kegemarannya baru muncul setelah larut malam. Namun demikian, tidak dipungkiri, sebagian dari penonton malam itu mengatakan bahwa kostum telah menarik perhatian mereka.

Sebuah pentas apapun, termasuk topeng betawi, tujuannya menggaet penonton sebanyak mungkin. Para pelaku seni ini ingin agar penonton menyenangi pentasnya dan sesering mungkin mereka mengundang kelompok mereka untuk pentas. Apabila penonton tidak menyukai atau mengabaikan hal tersebut adalah sebuah risiko dari pertunjukan seni.

Unsur-unsur yang ditunggu penonton dalam pertunjukan malam itu sebagian besar terfokus pada bodoran dan tarian. Bodoran berupa lawakan di bagian akhir pentas, sedangkan tarian merupakan penampilan tarian berdasarkan tata gerak (koreografi) dalam iringan musik yang dibawakan para penari yang mengenakan kostum tertentu. Sementara, perhatian lainnya diarahkan pada pertunjukan musik, berupa dangdut. Malam itu selain dari anggota kelompok sendiri, Kelompok Margasari Kacrit Putra juga menghadirkan seorang penyanyi dangdut lokal.

Bisa dinilai kehadiran kostum sebagai sarana visual pada pentas topeng betawi, tidak seutuhnya berhasil memikat penonton. Penonton sebagian tertarik pada bodoran, dan tidak terlalu perhatian pada kostum. Kemudian sebagian kecil lainnya menyukai musik.

Namun bila mengamati kehadiran penonton di sekitar panggung bisa menjelaskan hubungan antara pentas dan penontonnya. Pentas topeng betawi malam itu diawali pada pukul 20.00 dan diakhiri pada pukul 01.00 dinihari. Selama durasi 5 jam pertunjukan topeng betawi tersebut dapat diamati arus penonton, kapan penonton penuh dan kapan penonton kurang dalam kaitannya dengan jenis pentas di panggung.

Jumlah penonton memuncak pada saat pentas tari lipet gandes pukul 23.13. Para enonton mulai mengalir semenjak tari gegot yang dimulai pukul 21.25. Pada saat pentas tari topeng tunggal dan kemudian utamanya pada tari sarendong ajer penonton sudah memenuhi lahan kosong seluas sekitar 20x15 m persegi.

Kemudian pada saat berlangsung pertunjukan bodoran penonton masih bertahan di tempatnya. Penonton masih memenuhi area lapang pada pukul 00.14.

Pada waktu tengah malam tersebut penonton masih berkumpul, termasuk ibu-ibu dan anak-anak. Mereka tampak menikmati pertunjukan bodoran di atas gelaran tikar di bawah tenda yang telah disiapkan panitia.

Dengan demikian, unsur tarian dengan kostum aneka rupa dan bodoran merupakan unsur paling kuat dalam pertunjukan topeng betawi malam itu. Tari dan bodoran merupakan unsur pentas yang ditunggu-tunggu oleh penonton. Hal ini sejalan dengan pertimbangan dari Bang Udin selaku pimpinan untuk menghadirkan pelbagai tarian dan adanya bodoran.

Adanya beragam "menu" ini dipahami oleh Muhamad Sarif, ketua RW 01, bahwa topeng betawi dari Kelompok Margasari Kacrit Putra menawarkan beragam tampilan yang menarik. Di dalamnya ada pemain yang masih mudamuda, musiknya kombinasi antara yang modern dan tradisi, kostum bervariasi, bodoran menarik. Sehingga Muhamad Sarif sampai pada kesimpulan variasi panggung kelompok ini menarik. Demikian pula pendapat Nur dari pihak 
penonton mengatakan bahwa pertunjukan kelompok topeng betawi ini memiliki tarian dengan kostum bervariasi dan bodorannya bagus.

Adanya beragam "menu" ini berguna untuk menarik minat penonton sebanyak mungkin. Visualisasi kostum yang dikenakan pada penari memiliki daya pikat untuk menarik perhatian penonton. Sementara itu, sebagian lain yang tidak tertarik atau tidak perhatian pada kostum ternyata menyukai adanya bodoran. Tidak bisa dipungkiri kehadiran bodoran pada pentas topenge betawi Kelompok Margasari Kacrit putra adalah bagian dinanti oleh sebagian penonton.

\section{SIMPULAN}

Kostum tari kreasi yang dikenakan para penari memiliki daya tarik terhadap penonton dan pemiik hajat. Penonton dan pemilik hajat menilai kostum yang dikenakan para penari menarik perhatian mereka. Ketertarikan ini ditujukan kepada susunan aneka warna yang digunakan dan aksesoris yang dikenakan. Kostum ini utamanya diarahkan kepada pentas topeng betawi dari Kelompok Margasari Kacrit Putra. Mereka menilai kostum yang penari kenakan membuat pentas menjadi menarik. Mereka juga menganggap kostum penari merupakan ciri khas dari kelompok tersebut.

Meskipun demikian, kostum tari kreasi bukan satu-satunya unsur yang membuat penonton datang untuk menikmati pentas topeng betawi. Sebagian dari penonton tidak menganggap kostum tari kreasi sebagai sesuatu yang menarik hati mereka. Para penonton tersebut datang ke pentas topeng betawi lantaran menunggu bagian bodoran atau lawakan.

Untuk itu dalam kaitannya meningkatkan minat masyarakat untuk menonton pentas topeng Betawi, strategi visual membuat sebuah kostum para penari yang menarik harus dilakukan.
Kostum sebagai bagian dari aspek visual pentas topeng betawi dapat dikatakan sebagai bagian utamanya. Karena itu visual kostum harus mendapat prioritas dari para pelaku seni agar penonton dan pemilik hajat memperhatikan keberadaan mereka. Hal ini jelas pada pentas topeng betawi dari Kelompok Margasari Kacrit Putra.

Namun demikian, unsur visual ini bukan satu-satunya penentu kehadiran penonton dan adanya undangan pentas dari pemilik hajat. Bodoran atau lawakan merupakan unsur lainnya yang penting dalam pementasan topeng betawi. Bodoran merupakan bagian pentas topeng betawi yang dinanti penonton. Adanya bodoran yang lucu dan berhasil membuat penonton terpingkal-pingkal akan memberi kesan mendalam kepada penonton. Dari sinilah sebuah kelompok topeng betawi akan popular dan menjadi rujukan masyarakat Betawi dan sekitarnya bila akan mengundang pentas seni tradisi Betawi, khususnya topeng betawi.

Selanjutnya, mengenai isu ketertarikan penonton topeng betawi diarahkan pada dua unsur ini, yaitu visual dan bodoran. Penelitian ini untuk memahami secara mendalam bagaimana unsur visual dan bodoran memberi kesan kuat pada diri penonton. Untuk menguatkan kesimpulan tersebut perlu dilakukan penelitian kelompok topeng betawi yang tersebar dalam wilayah budaya Betawi. Hasil penelitian tersebut banyak manfaatnya untuk menyusun strategi secara utuh tentang bagaimana seni tradisi topeng betawi dapat bertahan di kawasan metropolitan Jakarta, Bekasi, Bogor, Depok, dan Tangerang.***

\section{DAFTAR PUSTAKA}

Berger, J. (1972). Ways of Seeing. Great Britain: British Broadcasting Corporation and Penguin. 
Caturwati, E. (2007). Tari di Tatar Sunda. Bandung: Sunan Ambu Press-STSI Bandung

Kleden, N. (1996). Lenong Betawi, Studi Perbandingan Diakronik, Yayasan Obor dan Yayasan Asosiasi Tradisi Lisan. Jakarta, 1996.

(1987). Disertasi Universitas Indonesia. Teater Topeng Betawi sebagai Teks dan Maknanya: Suatu Tafsiran Antropologi.
Nalan, A.S. (1996). Kapita Selekta Tari. Bandung: STSI Press Bandung.

Utami, P. (2013). Tesis di Universitas Indonesia. Topeng Betawi: Dari Balik Tirai Ke Panggung.

\section{Jurnal}

Schele, J. (2017). "Contesting Javannese Traditions" dalam Indonesia and the Malay World. Volume 45. Issue 131. Hal. 10. 